\title{
Anuran diversity indicates that Caatinga relictual Neotropical forests are more related to the Atlantic Forest than to the Amazon
}

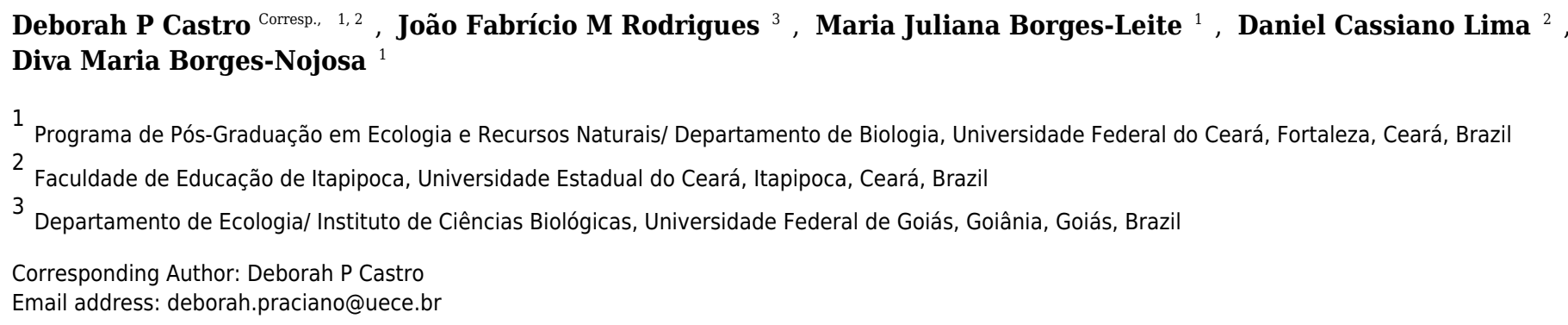

The relationships among the morphoclimatic domains of South America have been a major biogeographical issue of recent years. Palynological, geological and phytogeographical data suggest that the Amazon Forest and the Atlantic Forest were connected during part of the Tertiary and Quaternary periods. This study uses amphibians as model organisms to investigate whether relict northeastern forests are a transition between the Amazon Forest and the Atlantic Forest. We compiled matrices of species composition for four different phytogeographic formations and "Brejos de Altitude", and analyzed them using clustering methods and Cladistic Analysis of Distributions and Endemism (CADE). Our results indicate that the anurofauna of these northeastern forest relicts is most similar in composition to the areas of the Atlantic Forest included in this study, and most dissimilar to the Amazon Forest, which leads us to affirm that events of biotic exchange were more frequent within the Atlantic Forest areas. 
1 Anuran diversity indicates that Caatinga relictual Neotropical forests are more related to 2 the Atlantic Forest than to the Amazon.

3

4 Déborah P Castro ${ }^{1,3}$, João Fabrício M Rodrigues², Maria Juliana Borges-Leite ${ }^{1}$, Daniel Cassiano 5 Lima $^{3}$, Diva Maria Borges-Nojosa ${ }^{1}$

$6{ }^{1}$ Programa de Pós-Graduação em Ecologia e Recursos Naturais, Departamento de Biologia,

7 Universidade Federal do Ceará, Fortaleza/ CE, Brazil.

$8{ }^{2}$ Departamento de Ecologia, Instituto de Ciências Biológicas, Universidade Federal de Goiás, 9 Goiânia/ GO, Brazil.

$10{ }^{3}$ Faculdade de Educação de Itapipoca, Universidade Estadual do Ceará, Itapipoca/ CE, Brasil.

11 Corresponding Author: Déborah Castro

12 Email address: deborahpraciano@gmail.com 
24

25

\section{ABSTRACT}

The relationships among the morphoclimatic domains of South America have been a major biogeographical issue of recent years. Palynological, geological and phytogeographical data suggest that the Amazon Forest and the Atlantic Forest were connected during part of the Tertiary and Quaternary periods. This study uses amphibians as model organisms to investigate whether relict northeastern forests are a transition between the Amazon Forest and the Atlantic Forest. We compiled matrices of species composition for four different phytogeographic formations and "Brejos de Altitude", and analyzed them using clustering methods and Cladistic Analysis of Distributions and Endemism (CADE). Our results indicate that the anurofauna of these northeastern forest relicts is most similar in composition to the areas of the Atlantic Forest included in this study, and most dissimilar to the Amazon Forest, which leads us to affirm that events of biotic exchange were more frequent within the Atlantic Forest areas.

\section{INTRODUCTION}

The relationships among the morphoclimatic domains of South America have been a major biogeographical issue of recent years (Pellegrino et al., 2005; Cabanne et al., 2007; Werneck, 2011; Werneck et al., 2011; Werneck et al., 2012; Sobral-Souza \& Lima-Ribeiro, 2017). Efforts to understand these relationships have identified climatic fluctuations of the Quaternary as the main driver of the current distribution of the main forest vegetation types in the Neotropics (Haffer, 1969; Andrade-Lima, 1982; Haffer \& Prance, 2002; Martins et al., 2009). Results of palynological (Pierre-Ledru et al., 1996; Oliveira, Barreto \& Suguio, 1999; Bush \& Oliveira, 2006), geological (Oliveira, Barreto \& Suguio, 1999), phytogeographical (Pierre-Ledru, SalgadoLabouriau \& Lorscheitter, 1998; Auler et al., 2004; Santos et al., 2007) and zoogeographical (Borges-Nojosa \& Caramaschi, 2003; Costa, 2003; Batalha-Filho et al., 2013) studies suggest that the Amazon Forest and the Atlantic Forest were linked, thereby enabling the exchange of species (Connor, 1986; Borges-Nojosa \& Caramaschi, 2003; Borges-Nojosa, 2007;Carnaval \& Bates, 2007; Batalha-Filho et al., 2013). 
The effects of Quaternary climatic fluctuations are evident in northeastern Brazil (Santos et al., 2007), which is predominantly comprised of areas of Caatinga but also features forest relicts described by Andrade-Lima (1966) and Veloso, Rangel-Filho \& Lima (1991) as Seasonal Evergreen Forests (Florestas Estacionais Sempre-Verdes). These forests occur on mountains, plateaus and plains of approximately $900 \mathrm{~m}$ in elevation, generally located near the coast and whose windward slopes are wetter than the semiarid leeward slopes due to orographic rain (Araújo et al., 2007). They were named "Brejos de Altitude" (Relictual Forests) by Andrade \& Lins (1964) and Andrade-Lima (1966; 1982), and are remnants of vegetation that was probably continuous along the northeast coast of Brazil forming biological corridors between the Amazon Forest and the Atlantic Forest in wetter paleoclimatic periods. They also seem to be refuges within the Caatinga domain for species of these two forest biomes (Auler \& Smart, 2001; Borges-Nojosa \& Caramaschi, 2003; Auler et al., 2004).

The presence of species with disjunct distributions, distributions that encompass the northeastern "Brejos de Altitude" and either the Amazon Forest or the Atlantic Forest (or both), also suggests that the "Brejos-de-Altitude" acted as corridors connecting the two forest biomes (Andrade-Lima, 1966; Rizzini, 1967; Batalha-Filho et al., 2013). However, how these connections occurred is not yet fully clear, with two hypotheses currently being used to explain them (Fiaschi \& Pirani, 2009). According to Coimbra-Filho \& Câmara (1996), connections between the Atlantic Forest and the Amazon Forest occurred along the northeastern Atlantic coast, but were destroyed when European settlement began. Based on palynological studies conducted in the Icatu River Valley, Bahia, Oliveira, Barreto \& Suguio (1999) found a past plant assemblage that was comprised of species of both the Amazon Forest and the Atlantic Forest, suggesting that a forested ecosystem linking these biomes once existed. This evidence seems to agree with the connection hypothesis suggested by Oliveira-Filho \& Ratter (1995), who claimed the existence of a network of riparian forests in Caatinga and Cerrado that were responsible for the links between the Amazon Forest and the Atlantic Forest.

According to Connor (1986) and Carnaval (2002), modern distributions of species may be used both to infer local Pleistocene refuges and to test for links among them. In this way, we believe that species with low individual mobility and high philopatry to their natural sites still present a geographical distribution similar to that found in the Pleistocene, and can serve as a 
81

model to indicate connections between the Amazon and the Atlantic Forest. Taking this assertion into account, we use amphibians as model organisms for understanding the historical relationship among Brazilian biomes. Populations of amphibians have a tendency to be genetically structured even over short geographical distances and can retain signal of historical events that can be helpful in determining their current distribution (Zeisset \& Beebee, 2008), reinforcing that modern distributions of these animals may be used to infer area relationships. This study aims to evaluate the relationships between the "Brejos de Altitude" in northeastern Brazil and the Amazon Forest and the Atlantic Forest using the composition of anuran assemblages. We used anurans as a model to test the hypothesis that "Brejos de Altitude" functioned as important corridors connecting these two forested Brazilian biomes, as suggested by AndradeLima (1982). We expected the current anuran fauna of the "Brejos de Altitude" to have a high proportion of species in common with the Amazonian and Atlantic forest formations.

\section{MATERIAL AND METHODS}

\section{Data Selection}

We performed a search for studies with data on species composition of frog assemblages of the northeastern "Brejos de Altitude" and of the three Brazilian phytogeographic formations probably connected in the past: (1) Amazon (Amazon and pre-Amazon region), (2) Atlantic (north, and southeastern/south components) and (3) Cerrado. We also collected anuran composition data from Caatinga (sensu strictu) because it constitutes the landscape matrix in which "Brejos de Altitude" are located. The searches were conducted using ISI Web of Science, SciELO and Google Scholar. We also searched references found in the original articles, publications of the Ministério do Meio Ambiente (MMA) and banks of dissertations and theses. Searches used combinations of the keywords (Species *) and (* diversity and richness) and (* Amazon, Atlantic Forest, Cerrado * * Caatinga, "Brejos-de-altitude" and * anurans *). We reviewed all publications available on the website of the MMA for each phytophisiognomy with assemblages with defined frog species composition. We only selected studies that had a clearly defined study site with known geographical coordinates and known species composition and richness for its frog assemblage. To avoid problems related to taxonomic bias, we excluded from 
110 the analysis species that were cited as undetermined in the original publications which included

111 all those registered as "sp" (unidentified species), "gr" (group), "cf” (confers) and "aff" (affinis),

112 according to the criteria proposed by Araújo, Condez \& Sawaya (2009) and Forlani et al.,

113 (2010). To minimize misinterpretation due to the "effect of the taxonomist" we checked

114 synonyms using Amphibian Species of the World (Frost, 2018).

\section{Data Analysis}

117

118

119

120

121

122

123

124

125

126

127

128

129

130

131

132

133

134

135

136

137

138

We first constructed a presence-absence matrix where the columns represented species, and the rows represented sites. After we calculated compositional dissimilarities between the study sites using the Sorensen and Simpson indexes, which are commonly used in ecological and biogeographic studies and evaluate different forms of composition change (Koleff et al., 2003). We used clustering methods to evaluate the relationships between different study sites (Rosen, 1992; Ron, 2000). We used Cladistic Analysis of Distributions and Endemism (CADE) to generate a testable hypothesis of area-relationships between the "Brejos de Altitude" in northeastern Brazil and the Amazon Forest and the Atlantic Forest using the composition of anuran assemblages. CADE is an appropriate method for examining biogeographical signal, provided hierarchical information is incorporated and sample size is large (Porzecanski; Cracraft, 2005; Nihei, 2006). CADE was implemented in the software TNT (Tree Analysis Using New Technology) Version 1.5 (Goloboff; Catalano, 2016). In CADE analysis, we included a new "area" containing only zeros in our presence-absence matrix to represent the "outgroup" site. We also included the distribution of the genders and families of the species sampled in our literature search. Tree searches were performed using 1000 replicates of Wagner trees followed by the TBR (Tree Bisection Reconnection) swapping algorithm saving 10 trees per replication. We generated a strict consensus tree using the most parsimonious trees found and evaluated the support of this tree using the Bremer support. We grouped study sites by their dissimilarities using an Unweighted Pair Group Method using Arithmetic averages (UPGMA) algorithm. Second, we ordered areas using non-metric multidimensional scaling (NMDS). We used the statistical software R (R Development Core Team, 2010) and the package "Vegan" (Oksanen et al., 2010) for the implementation of these analyses. 
139

140

141

142

143

144

145

146

147

148

149

150

151

152

153

154

155

156

157

158

159

160

161

162

163

164

165

166

167

\section{RESULTS}

We found 93 publications that addressed 113study sites that met the criteria established for this research. We found a total richness of 423 species of frogs distributed among eleven (11) locations of "Brejos de Altitude", 22 of Amazon Forest, 14 of Caatinga, 30 of Cerrado and 36 of Atlantic Forest, the latter being divided into northeastern (14) and southeastern/south (22) regions (Figure 01 and Supplementary materials). The dendrograms from the UPGMA analyses had similar results, with a slight inconsistency between them. The Simpson's UPGMA showed that Amazon Forest sites are all clustered in a single group and that southeastern/south Atlantic Forest sites are clustered together with Cerrado (Figure 2). Only two areas of northeastern Atlantic Forest are found within these South-Southern Atlantic Forest groups. In contrast, Sorensen's UPGMA demonstrated that at least four areas of the Southeast / South Atlantic Forest are closely linked to the Amazon Rainforest (Figure 3). The study sites of "Brejos de Altitude" had species compositions more similar to areas of the northeastern Atlantic Forest and Caatinga, being located with those in the dendrograms. Cophenetic Correlation Coefficients were high (Sorensen=0,880 and Simpson=0,838), indicating that the dendrograms are adequately representing real dissimilarities among sites.

NMDS highlighted the existence of the five distinct groups found in UPGMA: (1) Amazon Forest; (2) Cerrado (3) southeastern Atlantic Forest; (4) northeastern Atlantic Forest and (5) Caatinga, "Brejos de Altitude" (Figure 4 and 5). The northeastern Atlantic Forest also formed a point of intersection between the southeastern Atlantic Forest and the group of "Brejos de Altitude" and Caatingas. The Cerrado are closely linked to southeastern Atlantic Forest. The stress values of the NMDS analyses were 0.181 (Sorensen) and 0,189 (Simpson) for the two dimensions, indicating that there is little distortion in the data and the distances are well supported. We compared the data from these analyses (UPGMA and NMDS) and found that areas of "Brejos de Altitude" had greater similarity with Caatinga and areas of northeastern Atlantic Forest.

The tree search found 100 most parsimonious trees, which had a score of 2198 . The eleven "Brejos de Altitude" were divided into five groups on our consensus cladogram (Figure 6): (1) Two "Brejos de Altitude" (Serra da Guia- BSEGUI and Brejo dos Cavalos- BPECAV) 
168 located in Sergipe and Pernambuco formed a basal polytomy with all others phytogeographic 169 formations; (2) Two areas located in the State of Pernambuco (Triunfo- BPETRI and Buíque-

170

171

172

173

174

175

176

177

178

179

180

181

182

183

184

185

186

187

188

189

190

191

192

193

194

195

BPECAT); (3)Two areas located in the State of Ceará (Serra de Maranguape- BCEMAR and Ibiapaba- BCEIBI); (4) Three areas located in the State of Ceará (Juazeiro- BCEJUA, CratoBCECRA and Barbalha- BCEBAR); and (5) one area located in Ceará (Baturité - BCEBAT) and one area of Pernambuco (Serra Negra- BPENEG) formed a single group and were closest to areas of Caatinga.

The CADE generally reinforced the results found in the cluster analysis: 1) the Amazon Forest formed a clade separated from all other vegetation types; 2) the CADE seems to reinforce that the areas of "Brejos de Altitude" are most commonly found closer to the Caatinga and Atlantic Forest Northeast.

\section{DISCUSSION}

In our study, we found that anuran assemblages of "Brejos de Altitude" are more similar to areas of Caatinga and Atlantic Forest in northeastern Brazil than to the Amazon Forest. Besides, "Brejos de Altitude" sites are also more similar to distant areas of southeastern/south Atlantic Forest and Cerrado, than to Amazon areas. These results contradict the hypothesis of AndradeLima (1982) and Bigarella \& Andrade-Lima (1982) who proposed that the Atlantic Forest and Amazon Forest were interconnected via the "Brejos de Altitude" of northeastern Brazil, and that the current distribution of species resulted from the fragmentation of this ancestral biota.

The great similarity between "Brejos de Altitude" and the northeastern Atlantic Forest was also found by other authors. Borges-Nojosa \& Caramaschi (2003) and Borges-Nojosa (2007), studied the distribution of reptiles in "Brejos de Altitude" in the state of Ceará, and found greater similarity to areas of Atlantic Forest. Tabarelli et al., (2004) and Rodal et al., (2008) found similar results for plants of "Brejos de Altitude". In a phylogeographic study of two species of anurans, Proceratophrys renalis (Miranda-Ribeiro, 1920) and Pristimantis gr. ramagii (Boulenger 1888), from "Brejos de Altitude", Carnaval \& Bates (2007) concluded that these areas are more closely related to the Atlantic Forest than to the Amazon Forest. 
197

198

199

200

201

202

203

204

205

206

207

208

209

210

211

212

213

214

215

216

217

218

219

220

221

222

223

component unlike other areas located further north, was also found by some other studies (Amorim \& Pires, 1996; Costa et al., 2000; Silva et al., 2004; Carnaval et al., 2009). Muller (1973) distinguished three different sub-centers in the Atlantic Forest (Pernambuco, Bahia and São Paulo). Our results demonstrate that this pattern of differentiation is valid for anurans as well. There is greater similarity between the northeastern component of the Atlantic Forest and areas of "Brejos de Altitude". This similarity may be explained by historical factors and the small geographical distance between the areas of this study.

We also found a high degree of similarity between "Brejos de Altitude" and Caatinga. According to Borges-Nojosa \& Caramaschi (2003) the influence of Caatinga on the species composition of the "Brejos de Altitude" is undeniable because this semiarid biome is the matrix in which the relictual forests are inserted. The strong association of "Brejos de Altitude", northeastern Atlantic Forest and Caatinga suggest that "Brejos de Altitude" be considered an ecotone region. Ecotones are transition zones between two adjacent ecological systems. They contain organisms of each of the overlapping communities and organisms that are restrict to the ecotone (Holland, 1988; Risser, 1995), thereby making them of great interest to conservationists (McArthur \& Sanderson, 1999).

Genetic studies of species found in the humid "Brejos de Altitude" in northeastern Brazil suggest that they do not all have the same evolutionary histories (Carnaval, 2002; Carnaval \& Bates, 2007), and probably resulted from two different former expansions that occurred in the Holocene and Pleistocene (Borges-Nojosa \& Caramaschi, 2003). In our analysis, areas of "Brejos de Altitude" were not also clustered in a single group, reinforcing these possible multiple origins of these areas. Probably the hypothesis of the "Brejos de Altitude" being a natural biogeographical unit of Silva \& Castelleti (2003) is not valid. Carnaval \& Bates (2007) suggest that the "Brejos de Altitude" do not have a common biogeographical origin, and Vanzolini (1981) and Borges-Nojosa \& Caramaschi (2003), already highlighted that the patterns of distributions of species of amphibians and reptiles show that each currently recognized "Brejo de Altitude" has a unique composition of species. 

assertion corroborates that proposed by Batalha-Filho \& Miyaki (2014), which states that the processes of diversification within the Brazilian phytogeographic formations may possibly be related to the ecological dependencies and the requirement of habitats inherent to the characteristics of each organism. Prance $(1979,1982)$, in a study of plants, and Teixeira et al., (1986) with birds, concluded that the Amazon influence on these groups is greater than the Atlantic influence. Anurans, unlike birds and certain plants that can be easily dispersed, have low individual mobility and do not usually disperse over long distances (Ron, 2000; Zeisset \& Beebee, 2008). This may explain the greater influence of the northeastern Atlantic Forest areas on the anuran fauna of the "Brejos de Altitude" since they are geographically closer than the Amazonian areas.

The fact that Sorensen's UPGMA has indicated that some areas of the Southeastern Atlantic Forest have species composition similar to some areas of the Amazon seems to indicate that these areas may share a common history. Probably, the historical contacts between these phytogeographic formations comprise distinct temporal connections (Batalha-Filho et al., 2013) through the Cerrado and the Caatinga. On the other hand, despite the evidence found in our study that contradicts a link between the northeastern "Brejos de Altitude" and the Amazon

241 Forest, we cannot be certain that these links have not occurred in the recent past. The disjunct distributions of some taxa indicate that there may have been conditions in the Pleistocene that allowed the expansion of rainforests (Andrade-Lima, 1982; Pennington et al., 2000; Santos et al., 2007; Borges-Nojosa et al., 2017.). Such disjunct distributions have been recorded for plants (Santos et al., 2007), birds (Teixeira et al., 1986), mammals (Costa, 2003) lizards and amphisbaenids (Borges-Nojosa \& Caramaschi, 2003). At least two genera of frogs (Pristimantis and Adelophryne) have such a disjunct distribution, occurring in "Brejos de Altitude" and in other forested areas of Brazil.

\section{CONCLUSIONS}

251 Our results indicate that the anuran fauna of "Brejos de Altitude" is most similar in composition 252 to areas of the Atlantic Forest and highly dissimilar to areas of the Amazon Forest and Cerrado. 
253 In addition, the northeastern "Brejos de Altitude" seem to have different histories and have a 254 strong ecotonal character, which reinforces the importance of conservation of these formations. 255 To better understand the current distribution of taxa of these relictual forests and how historical 256 and geological processes have shaped their distribution, more inventories and phylogeographic 257 studies of frog species for the "Brejos de Altitude" and Caatinga are needed.

\section{ACKNOWLEDGMENTS}

260

261

262

263

264

265

266

267

268

269

270

271

272

273

274

275

276

We thank Geraldo Jorge Barbosa de Moura, Marinus Steven Hoogmoed, Mirco Solé and Paulo Cascon for provided valuable comments which helped us to improve the manuscript. We are grateful to David James Harris and Eric Wild, who revised the English version of this manuscript.

\section{REFERENCES}

Amorim DS, Pires MRS. 1996. Neotropical biogeography and a method for maximum biodiversity estimation. In: Bicudo CEM, Menezes WA. Biodiversity in Brazil, a first approach.183-219. CNPQ, São Paulo.

Andrade-Lima D. 1966. Esboço fitoecológico de alguns "brejos" de Pernambuco. Arquivos do Instituto de Pesquisas Agronômicas de Pernambuco. 8: 3-9.

Andrade-Lima D. 1982. Present day forest refuges in Northeastern Brazil. In: Prance GT. Biological Diversification in the Tropics. Columbia University Press, New York, p. 245-254.

Andrade GO, Lins RC. 1964. Introdução ao estudo dos “Brejos” pernambucanos. Arquivos do Instituto de Ciências da Terra. 2: 21-34.

Araújo CO, Condez TH, Sawaya RJ. 2009. Anfíbios Anuros do Parque Estadual das Furnas do Bom Jesus, sudeste do Brasil, e suas relações com outras taxocenoses do Brasil. Biota Neotropica. 9 (2): 77-98. 
277 Araújo FS, Gomes VS, Silveira AP, Figueiredo MA, Oliveira RS, Bruno MMA, Lima-Verde

278 LW, Silva EF, Otutumi AT, Ribeiro KA. 2007. Efeito da variação topo climática e estrutura da 279 vegetação da serra de Baturité, Ceará. In: Oliveira TS, Araújo FS. Diversidade e Conservação da 280 Biota da Serra de Baturité, Ceará.Edições UFC/COELCE: Fortaleza. p. 75-162.

281 Auler AS, Smart PL. 2001. Late quaternary paleoclimate in semiarid northeastern Brazil from U282 series dating of travertine and water-table speleothems. Quaternary Research.55: 159-167.

283

Auler AS, Wang X, Edwards RL, Cheng H, Cristalli PS, Smart PL, Richards DA. 2004.

Quaternary ecological and geomorphic changes associated with rainfall events in presently semiarid northeastern Brazil. Journal of Quaternary Science. 19(7): 693-701.

Batalha Filho H, Fjeldsa J, Fabre PH, Miyaki CY. 2013. Connections between the Atlantic and the Amazonian forest avifaunas represent distinct historical events. Journal of Ornithology. 154: 41-50.

Batalha-Filho H, Myaki CY. 2014. Processos evolutivos na Amazônia e na Mata Atlântica. Fronteiras: Journal of Social Technological and Environmental Science. 3: 34-44.

Bigarella JJ, Andrade-Lima D. 1982. Paleoenvironmental changes in Brazil. In: Prance GT. Biological Diversification in the tropics. 27-40. Columbia University Press, New York.

Borges-Nojosa DM, Caramaschi U. 2003. Composição e análise comparativa da diversidade e das afinidades biogeográficas dos lagartos e anfisbenídeos (Squamata) dos Brejos Nordestinos. In: Leal IR, Tabarelli M, Silva JMC. Ecologia e Conservação da Caatinga. UFPE, Recife:489540.

Borges-Nojosa DM. 2007. Diversidade de anfíbios e répteis na serra de Baturité, Ceará. In: OLIVEIRA, T. S.; ARAÚJO, F. S. Diversidade e Conservação da Biota da Serra de Baturité, Ceará.Edições UFC/COELCE. Fortaleza.

Borges-Nojosa DM, Castro DP, Lima DC, Bezerra CH, Maciel AO, Harris DJ. 2017. Expanding the known range of Caecilia tentaculata (Amphibia: Gymnophiona) to relict mountain forests in northeastern Brazil: linking Atlantic forests to the Amazon? Salamandra. 53 (3): 429-434. 
303 Bush MB, Oliveira PE. 2006. The rise and fall of the Refugial Hypothesis of Amazonian

304 Speciation: a paleoecological perspective. Biota Neotropica.6(1).

305 Cabanne GS, Santos FR, Miyaki. 2007. Phylogeography of Xyphorhynchus

306 fuscus(Passeriformes, Dendrocolaptidae): vicariance and recent demographic expansion in

307 southern Atlantic forest. Biological Journal of Linnean Society. 91: 73-84.

308 Carnaval AC. 2002. Phylogeography of Four Frog Species in Forest Fragments of Northeastern

309 Brazil- A Preliminary Study. Integrative Compared Biology.42: 913-921.

310 Carnaval AC, Bates JM. 2007. Amphibian DNA shows marked genetic structure and tracks

311 Pleistocene climate change in Northeastern Brazil. Evolution. 61 (12): 2942-2957.

312 Carnaval AC.; Hickerson MJ, Haddad CFB, Rodrigues MT, Moritz C. 2009. Stability Predicts

313 Genetic Diversity in the Brazilian Atlantic Forest Hotspot. Science.323: 785-789.

314 Carvalho CJB, Bortolanza MCC, Soares EDG. 2003. Distributional Patterns of Neotropical

315 Muscidae (Diptera). In: Morrone JJ, Llorent B. Una perspective latinoamericana de la

316 Biogeografia. : 236-274. Universidade Autônoma do México. Ciudad del México.

317 Coimbra-Filho AF, Câmara IG. 1996. Os limites originais do bioma Mata Atlântica na região

318 nordeste do Brasil. Rio de Janeiro: Fundação Brasileira para a Conservação da Natureza. 86p.

319 Connor EF. 1986. The role of Pleistocene forest refugia in the evolution and biogeography of

320 tropical biotas. Tree 1 (6): 165-168.

321 Costa L. 2003. The historical bridge between the Amazon and the Atlantic Forest of Brazil: a

322 study of molecular phylogeography with small mammals. Journal of Biogeography. 30: 71-86.

323 Costa LP, Leite YRL, Fonseca GAB, Fonseca MT.2000 Biogeography of South American forest

324 mammals: Endemism and diversity in the Atlantic Forest. Biotropica 32 (4b): 872-881.

325 Fiaschi P, Pirani JR. 2009. Review of plant biogeographic studies in Brazil. Journal systematics 326 of Evolution. 47(5): 477-496. 
327 Forlani MC, Bernardo PH, Haddad CFB, Zaher H. 2010. Herpetofauna do Parque Estadual

328 Carlos Botelho, São Paulo, Brasil. Biota Neotropica. 10 (3): 265-309.

329 Frost DR. 2018. Amphibian Species of the World: an Online Reference. Version 6.0.Electronic

330 Database accessible at http://research.amnh.org/herpetology/amphibia/index.html.American

331 Museum of Natural History, New York, USA.

332 Goloboff PA, Catalano SA. 2016. TNT version 1.5, including a full implementation of

333 phylogenetic morphometrics. Cladistics. 32: 221-238.

334 Haffer J.1969. Speciation in Amazonian forest birds. Science. 165: 131-137.

335 Haffer J, Prance GT 2002. Impulsos climáticos da evolução na Amazônia durante o Cenozoico: 336 sobre a teoria dos Refúgios da diferenciação biótica. Estudos avançados.16(46).

337 Holland MM. 1988. SCOPE/MAB technical consultations on landscape boundaries report of a 338 SCOPE/MAB workshop on ecótonos. Biological International Special Issue. 17: 47-106.

339 Koleff P, Gaston KJ, Lennon JJ. 2003. Measuring beta diversity for presence-absence data. 340 Journal Animal Ecology. 72: 367-382.

341 Lambshead PJD, Paterson GLJ. 1986. Ecological cladistics an investigation of numerical 342 cladistics as a method for analyzing ecological data. Journal of Natural History.20: 895-909.

343 Mcarthur ED, Sanderson SC. 1999. Ecotones: Introduction, Scale, and Big Sage Brush Example. 344 USDA Foreste Service Proceedings RMSP-P-11.

345 Martins FM, Templeton AR, Pavan ACO, Kohlbach BC, Morgante JS. 2009. Phylogeography of 346 the common vampire bat (Desmodus rotundus): Marked population structure, Neotropical 347 Pleistocene vicariance and incongruence between nuclear and mtDNA markers. BMC 348 Evolutionary Biology 9: 294.

349 Muller, P. 1973. The dispersal centres of terrestrial vertebrates in the neotropical N realm: a 350 study in the evolution of the neotropical N biota and its native landscape. W. Junk, The Hague. 
351 NIHEI, SS 2006. Misconceptions about parsimony analysis of endemicity. Journal of

352 Biogeography 33: 2099-2106.

353 Oksanen J, Blanchet, FG, Kindt R, Legendre P, O’hara RB, Simpson GL, Solymos P, Stevens

354 MHH, Wagner H. 2010. Vegan: Community Ecology Package. R Package version 1.17-6.URL

355 http://CRAN.R-project.org/package=vegan

356 Oliveira PE, Barreto AMF, Suguio K. 1999. Late Pleistocene/Holocene climatic and vegetational

357 History of the Brazilian Caatinga: the fossil dunes of the middle São Francisco River.

358 Palaeogeographical, Palaeoclimatic, Palaeoecology.152:319-337.

359 Oliveira-Filho AT, Ratter JA . 1995. A study of the origin of Central Brazilian forests by the 360 analysis of plant species distribution patterns. Edinburgh Journal of Botany. 52(2): 141-194.

361 Pellegrino KCM, Rodrigues MT, Waite AN, Morando M, Yassuda YY, Sites JW. 2005.

362 Phylogeography and species limits in the Gymnodactylus darwinii complex (Gekkonidae,

363 Squamata): genetic structure coincides with river systems in the Brazilian Atlantic forest.

364 Biological Journal of Linnean Society. 85: 13-26.

365 Pennington RT, Prado DE, Pendry CA. 2000. Neotropical seasonally dry forests and Quaternary

366 vegetation changes. Journal of Biogeography. 27: 261-273.

367 Pierre-Ledru M, Braga PIS, Soubies F, Fournier M, Martin L, Suguio K, Turci B 1996. The last

36850,000 years in the Neotropics (Southern Brazil): evolution of vegetation and climate.

369 Palaeogeographic, Palaeoclimatic, Palaeocology. 123: 239-257.

370 Pierre-Ledru M, Salgado-Labouriau ML, Lorscheitter ML. 1998. Vegetation dynamics in

371 Southern and central Brazil during the last 10,000 yr B. P. Review of Palaeobotany and

372 Palynology. 99: 131-142.

373 PORZECANSKI, AL, CRACRAFT, J 2005. Cladistic analysis of distributions and endemism 374 (CADE): using raw distributions of birds to unravel the biogeography of the South American 375 aridlands. Journal of Biogeography. 32: 261-275. 
376 Prance GT. 1979. The taxonomy and phytogeography of the Chrysobalanaceae of the Atlantic

377 coastal forests of Brazil. RevistaBrasileirade Botânica. 2: 19-39.

378 Prance GT. 1982. Forest refuges: evidences from woody angiosperms. In: PRANCE, G. T.

379 Biological Diversification in the tropics. Columbia University Press, New York. p. 137-158.

380 R Development Core Team (2010): $R$ : A language and environment for Statistical computing. R

381 foundation for Statistical Computing, Vienna, Austria. http://www.Rproject.org/

382 Risser PG. 1995. The Status of the science examining ecotones. BioScience.45: 318-325.

383 Rizzini A. 1967. Delimitação, caracterização e relações da flora silvehileana. Atas Simplificadas 384 da Biota Amazônica. Botânica.4:13-36.

Rodal MJN, Barbosa MRV, Thomas WW. 2008. Do the seasonal forests in Northeastern Brazil represent a single floristic unit? Brazilian Journal of Biology. 68: 467-475.

387 388

389

390

391

392

393

394

395

396

397

398

399

400

Ron SR. 2000. Biogeographic area relationships of lowland Neotropical rainforest based on raw distribution of vertebrates groups. Biological Journal of Linnean Society. 71: 379-402.

Rosen BR. 1992. Empiricism and the biogeographical black box: concepts and methods in marine palaeobiogeography. Palaeobiogeographic, Palaeoclimatic, Palaeocology. 92, 171-205.

Santos AMM, Cavalcanti DR, Silva JMC, Tabarelli M 2007. Biogeographical relationships among tropical forests in north-eastern Brazil. Journal of Biogeography.34: 437-446.

Silva JMC, Casteletti CHM. 2003. Status of the biodiversity of the Atlantic Forest of Brazil. In: GALINDO-LEAL, C.; CÂMARA, I. G. The Atlantic Forest of South America: biodiversity status, threats, and outlook. P. 43-59. Center for Applied Biodiversity Science and Island Press, Washington, DC.

Silva JMC, Souza MC, Castelleti CHM. 2004. Areas of endemism for passerine birds in the Atlantic Forest, South America. Global Ecology and Biogeography. 13: 85-92.

Sobral-Souza T, Lima-Ribeiro MS. 2017. De volta ao passado: revisitando a história biogeográfica das florestas neotropicais úmidas. Oecologia Australis. 21: 93-107. 
401 Tabarelli M, Silva JMC, Gascon C. 2004. Forest fragmentation, synergisms and the

402 impoverishment of neotropicalN forests. Biodiversity and Conservation 13: 1419-1425.

403 Vanzolini PE .1981 A quasi-historical approach to the natural History of differentiation of 404 reptiles in the tropical geographic isolates. PapéisAvulsos de Zoologia.34: 189-204.

405 Veloso HP, Rangel-Filho AL, Lima JCA. 1991. Classificação da vegetação brasileira, adaptada 406 a um sistema universal.IBGE, Rio de Janeiro. 123p.

407 Werneck FP. 2011. The diversification of eastern South American Open vegetation biomes:

408 Historical biogeography and perspectives. Quaternary Science Reviews. 30: 1630-1648.

409 Werneck FP, Gamble T, Colli GR, Rodrigues MT, Sites EJW. 2012. Deep diversification and 410 Long-Term Persistence in the South American 'Dry Diagonal': Integrating Continent-Wide 411 Phylogeography and Distribution Modeling of Geckos. Evolution. 66: 3014-3034.

412 Zeisset I, Beebee TJC. 2008. Amphibian phylogeography: a model for understanding historical 413 aspects of species distributions. Heredity, 101: 109-119. 
Figure 1

Map of the study area

Map of the study sites analyzed in the study. More details of each site may be found in the supplementary material. The different vegetation types are represented by colors:

southeast/south Atlantic Forest $=$ Purple; northeastern Atlantic Forest $=$ Navy Blue; Caatinga

$=$ Red $;$ Cerrado $=$ Orange; Brejos de Altitude $=$ Blue; Amazon $=$ Green. Map Author: Maria Juliana Borges-Leite.

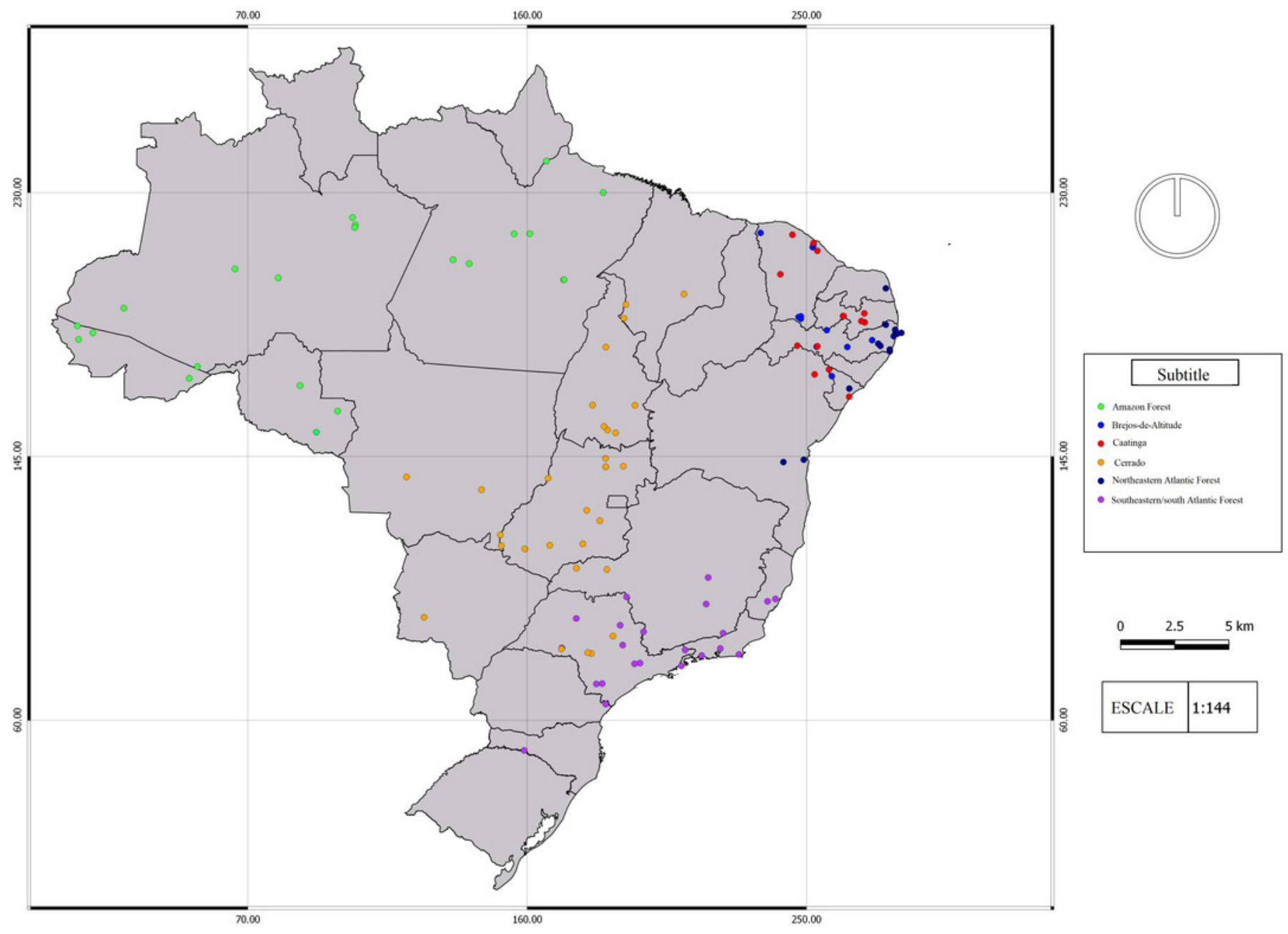


Figure 2

Non-metric multidimensional scaling (using Simpson index) of the 113 areas analyzed in this study.

Polygons represent the studied vegetation types: southeastern/south Atlantic Forest = Purple; northeastern Atlantic Forest $=$ Navy Blue; Caatinga $=$ Red; Cerrado $=$ Orange; Brejos de Altitude= Blue; Amazon = Green . 


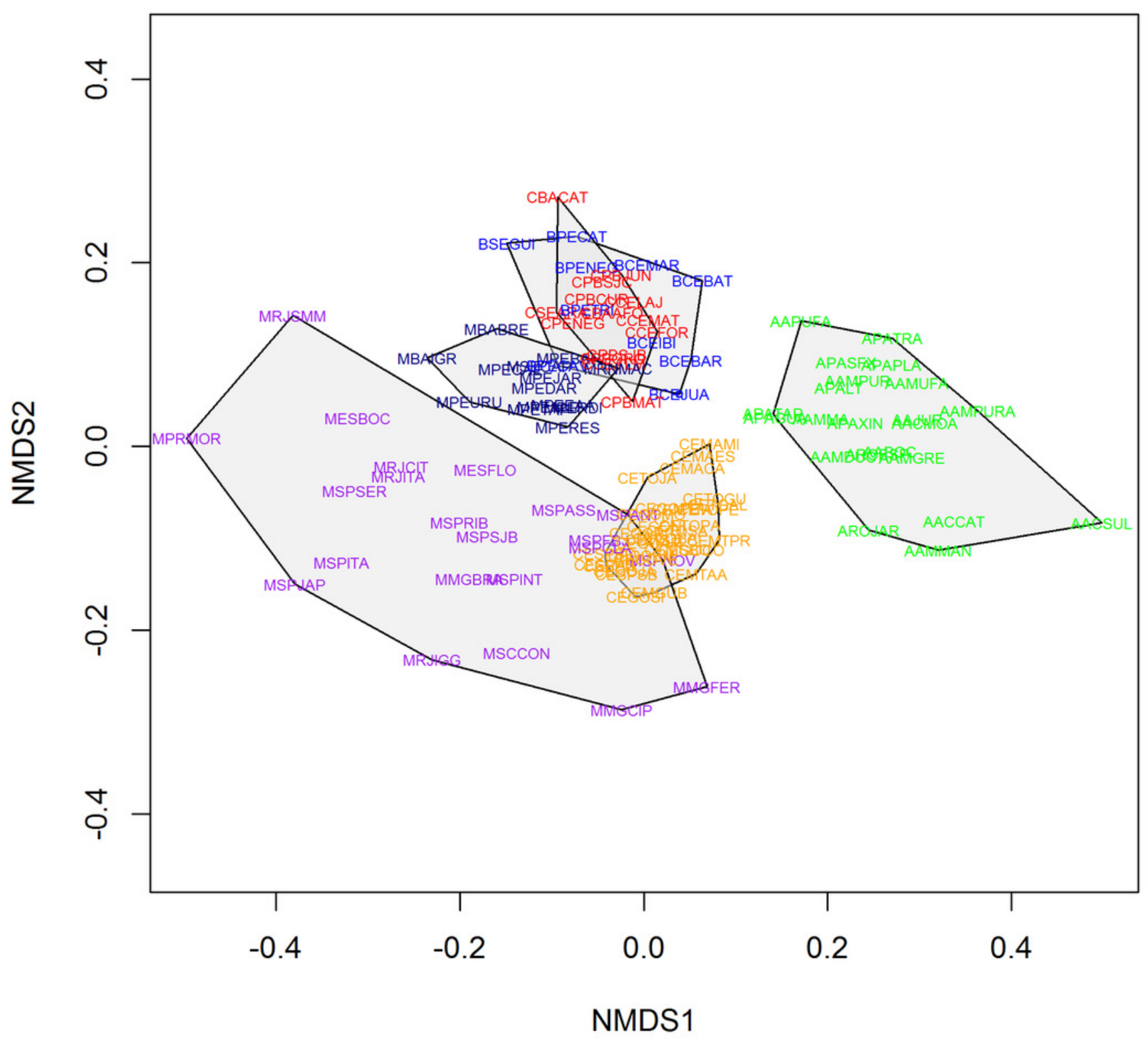




\section{Figure 3}

Non-metric multidimensional scaling (using Sorensen index) of the 113 areas analyzed in this study.

Polygons represent the studied vegetation types: southeastern/south Atlantic Forest $=$ Purple; northeastern Atlantic Forest $=$ Navy Blue; Caatinga $=$ Red; Cerrado $=$ Orange; Brejos de Altitude= Blue; Amazon = Green . 


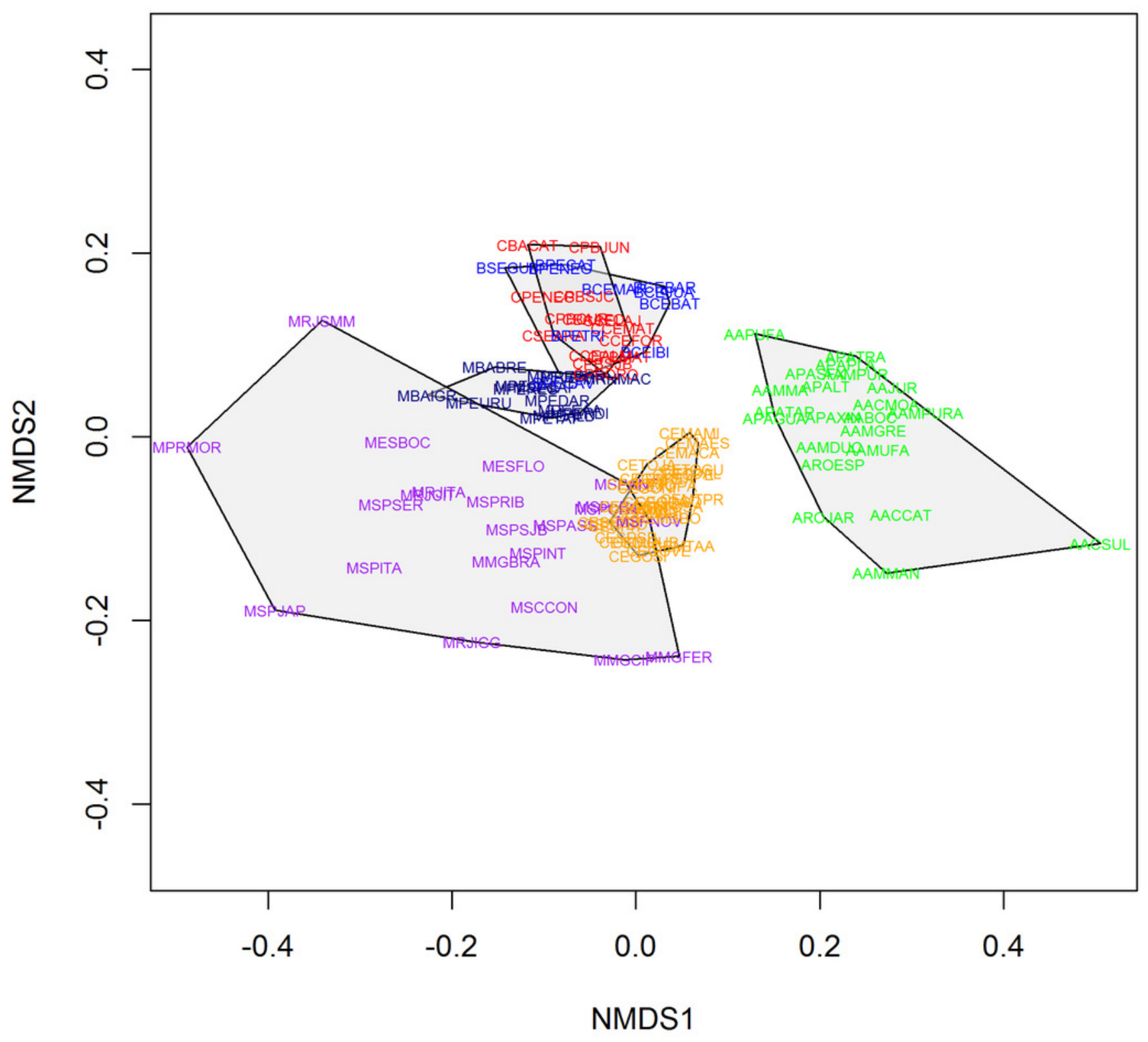




\section{Figure 4}

Dendrogram of similarity between study areas obtained using Unweighted Pair Group Method using Arithmetic averages (UPGMA) and Simpson index for 113 areas included in our study.

The areas are identified by codes found in the supplementary materials. The different vegetation types are represented by colors: southeastern/south Atlantic Forest = Purple; northeastern Atlantic Forest $=$ Navy Blue; Caatinga $=$ Red; Cerrado= Orange; Brejos de Altitude= Blue; Amazon = Green . 


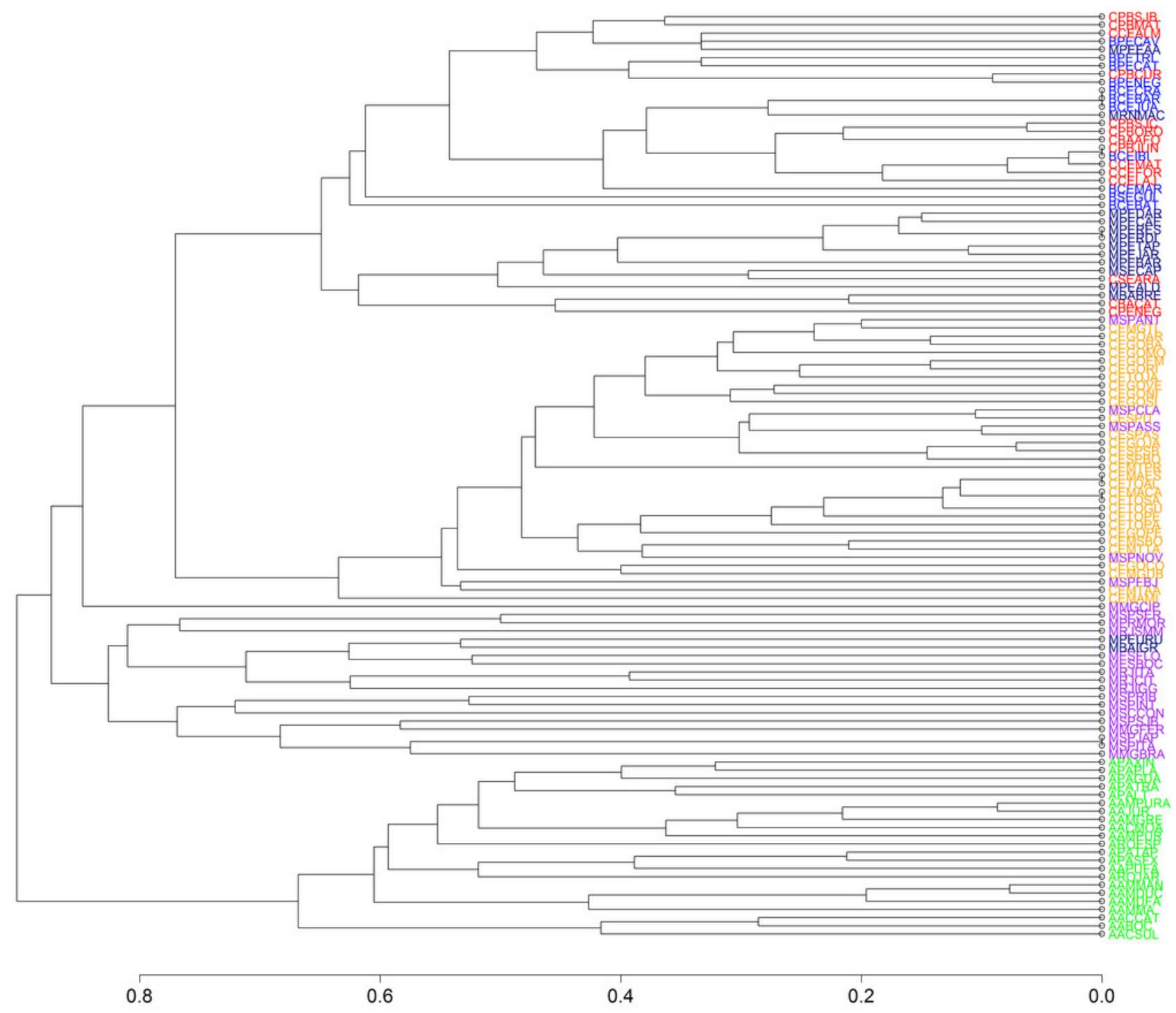




\section{Figure 5}

Dendrogram of similarity between study areas obtained using Unweighted Pair Group Method using Arithmetic averages (UPGMA) andthe Sorensen / Bray-Curtis index for 113 areas included in our study.

The areas are identified by codes found in the supplementary materials. The different vegetation types are represented by colors:southeastern/south Atlantic Forest = Purple; northeastern Atlantic Forest $=$ Navy Blue; Caatinga $=$ Red; Cerrado= Orange; Brejos de Altitude= Blue; Amazon = Green . 


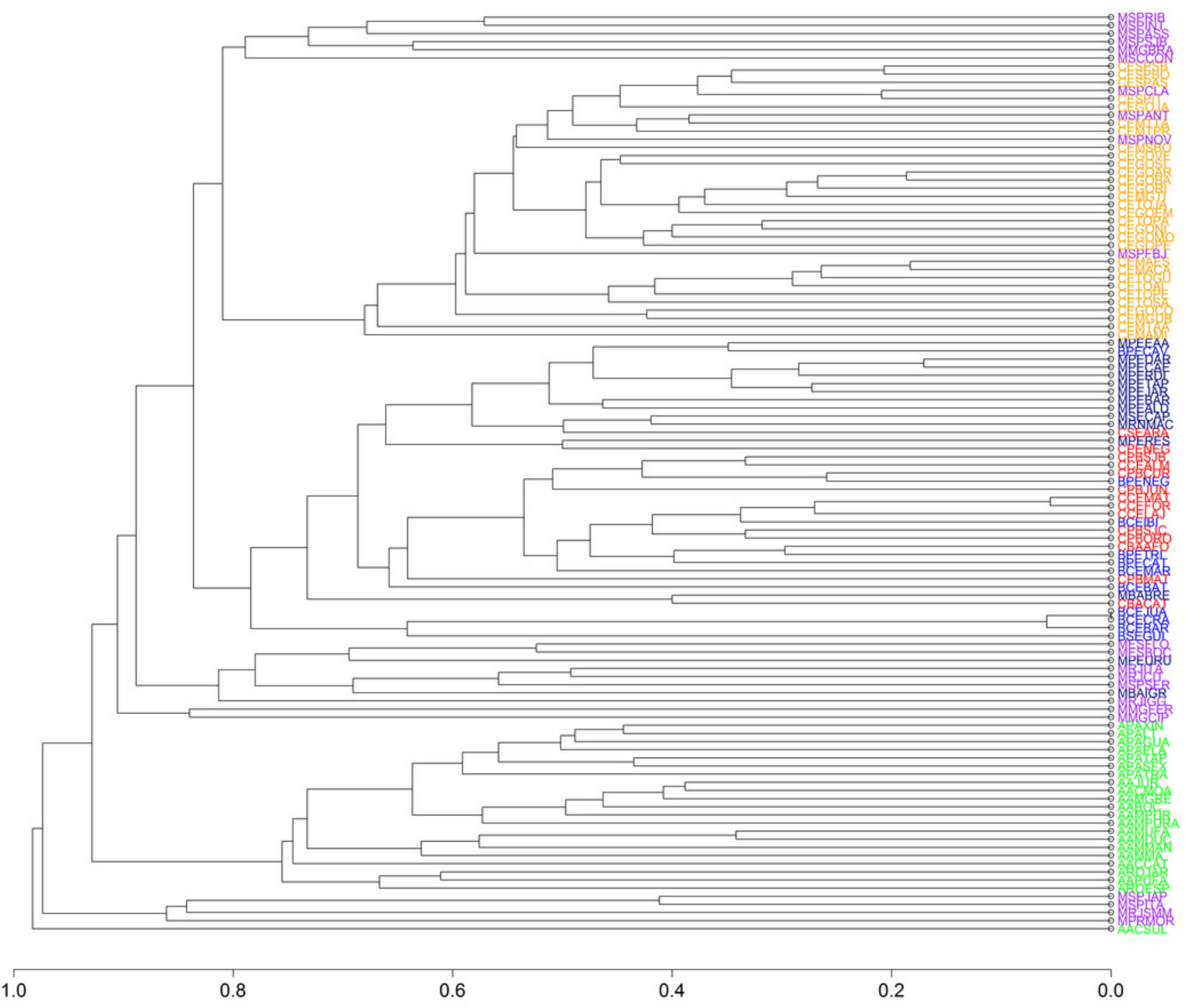




\section{Figure 6}

CADE Bremer support tree consensus.

The strict consensus tree derived from the 100 most parsimonious trees found using the cladistic analysis of distributions and endemism (CADE) for the 113 areas included in our study. Bremer supports are represented in the nodes of the strict consensus cladogram. The values "25?" mean that an increase of more than 25 steps is necessary to dissolve this clade. 
Bremer supports (from 9912 trees, eut of

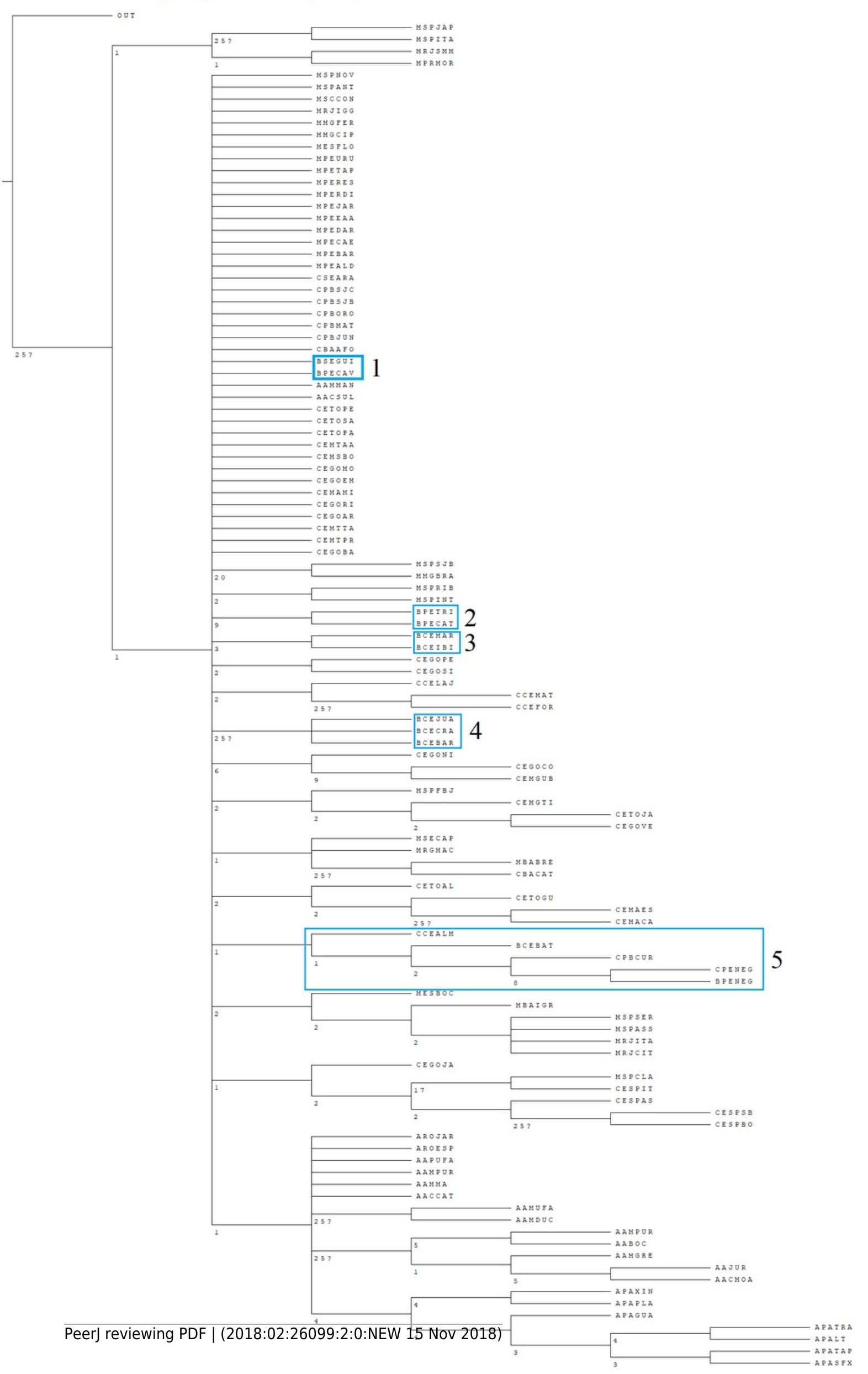

